\title{
Pandemi Günlerinde Geride Kalanlar Sendromu: Sağlık Çalışanları Üzerinde Bir İnceleme
}

\author{
DOI: $10.26466 /$ opus.875781
}

$*$

\author{
Sevilay Güler * \\ * Dr., Bağımsız Araştırmacı \\ E-Posta: dsg888@hotmail.com \\ ORCID: $\quad$ 0000-0003-3877-6894
}

\section{Öz}

Tüm dünyanın zorlu bir süreçten geçtiği pandemi günlerinde insanların sadece fizyolojik değil psikolojik sağlıkları da olumsuz etkilenmekte; bu etkiler çalışma ortamlarına ve çalışma ilişkilerine de yansımaktadır. Şüphesiz, bu durumdan en fazla etkilenen sağllk çalışanları bir yandan görevlerini yerine getirmeye çalışırken, bir yandan kendilerini ve ailelerini de koruma kaygısı duymaktadır. Birçok meslektaşlarının ölüm veya hastalığa yakalanma nedeniyle işten ayrıldığ bir çalışma ortamında işlerine devam edebilen ve yaşanan belirsizlik ortamında geride kalan bazı çalışanlarının olumsuz duygular içerisine girmesi kaçınılmazdır. Bu bağlamda bu çalışmanın amacı pandemi döneminde çalışmaya devam eden sağ lık çalışanlarının yaşadığı geride kalanlar sendromunu ortaya koymaktır. Pandemi sürecinde en ağır yükü göğüsleyen sağlık çalışanlarının her türlü sorunlarının ortaya konulmasının, onların işlerine devam edebilmeleri ve tüm insanlı̆̆ın să̆llkl bir yaşam sürebilmesi bakımından önemli olduğ $u$ düşünülmektedir. Nitel araştırma yöntemine göre tasarlanan araştırmada fenomenoloji deseni kullanılmıştır. Araştırma verileri araştırmacı tarafından geliştirilen yarı yapılandırılmış görüşme formu ile toplanmış ve toplanan veriler içerik analizi ve betimsel analiz yoluyla çözümlenmiştir. Yapılan araştırma sonucunda pandemi sürecinde sağ lı çalışanlarının yoğun bir şekilde geride kalanlar sendromu yaşadığ̆ ortaya konulmuş ve çözüm önerileri sunulmuştur.

Anahtar Kelimeler: $\quad$ Pandemi, geride kalanlar sendromu, sağlık çalışanları. 


\title{
Survivor Syndrome in Pandemic Days: A Study on Health Workers
}

\begin{abstract}
During the pandemic days when the whole world is going through a difficult process, not only the physiological but also the psychological health of people are negatively affected; these effects are also reflected in working environments and working relationships. Undoubtedly, health workers who are most affected by this situation are concerned about protecting themselves and their families while trying to fulfill their duties. It is inevitable that some employees who can continue their jobs in a work environment where many colleagues leave their jobs due to death or illness and who fall behind in an environment of uncertainty will feel negative emotions. In this context, the aim of this study is to reveal the survivor syndrome experienced by health workers who continue to work during the pandemic period. It is thought that revealing all kinds of problems of health workers who bear the heaviest burden during the pandemic process is important for their ability to continue their work and for the whole humanity to live a healthy life. Phenomenology design was used in the study designed according to the qualitative research method. The research data were collected by a semi-structured interview form developed by the researcher and the collected data were analyzed through content analysis and descriptive analysis. As a result of the research, it has been revealed that health workers experience the survivor syndrome intensely during the pandemic process and solutions have been offered.
\end{abstract}

Keywords: Pandemic, survivor syndrome, health workers. 


\section{Giriş}

Kadim zamanlardan beri insan hayatında salgın hastalıklar farklı dönemlerde ortaya çıkmak suretiyle var olagelmiştir. Daha önce karşılaşılmayan bulaşıcı bir hastalığın tüm dünyayı etkilemesi pandemi olarak ifade edilmektedir. T.C. Sağlık Bakanlığı' nın (2020) tanımına göre pandemi, bir hastalığın ya da enfeksiyon etkeninin ülkelerde, kıtalarda ve tüm dünyada yayılmasıdır. Dünya Sağlık Örgütü' nün (WHO, 2010) tanımına göre ise bir hastalığın pandemi kabul edilebilmesi için, daha önce rastlanmamış bir hastalık olması, hastalığa neden olan patojenin insanlara bulaşarak tehlikeli bir hastalığa neden olması ve hastalığa neden olan patojenin istikrarlı bir şekilde bulaşıcı olması gerekmektedir.

Günümüzde küreselleşme ile birlikte giderek artan insan hareketliliği ülkeler arası etkileşimi ciddi oranda artırmış, yoğun şehirleşme, küresel iletişim ve ulaşım imkanlarının gelişmesi, farklı insan ve hayvan türleri ile artan temas toplumları uygarlık bakımından ilerletmiş olsa da pandemilerin ortaya çıkma olasılığını da artırmıştır. İnsanlık tarihine bakıldığında bugüne kadar yirminin üzerinde pandemi ortaya çıtığı bilinmektedir. Bunların içerisinde en fazla can kaybına yol açan ve insanlığı en olumsuz şekilde etkileyen pandemiler veba, kolera, grip, AIDS ve Koronavirüs COVID-19 pandemileridir (Akcan vd., 2020, s.355). Pandemiler sona erse bile insanların psikolojisi üzerindeki olumsuz etkileri uzun süre devam edebilmektedir.

Geride kalanlar sendromu ya da diğer adıyla survivor sendromu, bir kişi travmatik veya trajik bir olaydan sağ çıkarken başkalarının yapmadığı bir şeyi yanlış yaptığına inandığında, genellikle kendini suçlu hissettiğinde ortaya çıkan zihinsel bir durumdur. Illk olarak 1960'larda tespit edilen survivor sendromu çatışma, doğal afetler, terörist saldırılar, hava kazaları ve çok çeşitli işten çıkarmalar gibi travmatik durumlardan kurtulanlarda (geride kalanlarda) gözlenen; endişe, kaygı, korku ve panik gibi olumsuz duyguların meydana getirdiği psikolojik bir sendromu ifade etmektedir (Doherty ve Horsted, 1995).

Geride kalanlar sendromunun ortaya çıkışı aslında Japonya'ya atılan atom bombası felaketine kadar gitmektedir. Yapılan araştırmalar sonucunda Japonya'da yaşanan atom bombası felaketi sonrasında hayatta kalan kişilerin çok büyük bir kısmında endişe, kaygı, korku ve panik gibi olumsuz duyguların bir psikolojik bir sendrom meydana getirdiği anlaşılmıştır. Buna göre, 
atom bombası atılmasının ardından kişilerde görülen korku belirtileri ve benzerlerinin, örgütsel küçülme dönemlerinde çalışanlarda, aynı korkuların sadece biraz daha düşük yoğunlukta gerçekleştiği görülmüştür (Gemlik, Önal ve Taşdemir, 2011).

20 yılı aşkın süre boyunca travmadan kurtulanlar üzerinde araştırmalar yapan ünlü psikolog Stephen Joseph, 459 yolcudan 193'ünü öldüren meşhur deniz kazası MS Herald of Free Enterprise'in alabora olmasindan kurtulan kişilerin psikolojik durumlarını incelemiştir. Buna göre kaza sonrası hayatta kalanların yüzde 60'ının hayatta kalmalarından dolayı suçluluk duygusu hissettiği tespit edilmiştir. Araştırma bulgularına göre geride kalanlardan bazıları diğerleri ölürken hayatta kalmış olmaktan suçluluk duymaktayken, bazıları ölenler için yapamadıkları şeyler yüzünden suçluluk duymakta, bazıları da olay esnasında başkalarının üzerinden kaçmak için çabalamak gibi yaptıkları şeyden suçluluk duymaktaydılar. Sonuç olarak hepsinde ortak olarak gözlenen olumsuz bir duygu durumuna maruz kaldıkları, suçluluk, öfke, endişe, korku gibi hisler barındıran bir psikolojik sendrom yaşadıkları tespit edilmiştir. Geride kalanlar çoğu zaman, hayatta kalanı kurtarmaya çalışırken ölen kişilerin ya da kurtarmaya çalışmadıkları kişilerin ölümünden dolayı kendilerini sorumlu tutmaktadırlar (Bonnie ve Steven, 2010, s.33).

Toplama kampı sendromu olarak da bilinen geride kalanlar sendromu, büyük ve olumsuz olaylardan kurtulmuş insanların tepkilerini ve davranışlarını tanımlamak için kullanılan bir kavramdır (Ryn, 1990). Hollandalı psikiyatrist Eddy de Wind, Auschwitz toplama kampindan kurtulduktan sonra yaşadığı zulmün psikolojik sonuçlarına ilişkin "toplama kampı sendromu" kavramını geliştirerek eski Nazi toplama ve imha kamplarındaki mahkumlara özgü patolojik sonradan etkileri analiz etmiştir. Soykırım mağdurları arasında çok yüksek oranda kendini gösteren sendrom anksiyete ve depresyon, zihinsel bozukluk, sosyal geri çekilme, uyku bozukluğu ve kabuslar, fiziksel şikayetler ve dürtü kaybıyla birlikte ruh hali değişimlerini içermektedir. Genellikle bu tür geride kalanlar, yaşadıkları trajik olaydan kurtuldukları/ geride kaldıkları ve aileleri, arkadaşları ve meslektaşları bunu yapamadıkları için kendilerini suçlu hissetmektedirler (Lebovic, 2020).

Survivor sendromunu literatürde ilk olarak nedenleri ve sonuçlarını tanımlayarak kavramsallaştıran William G. Niederland, Nazi toplama kamplarından kurtularak hayatta kalan kurbanların katlandığı acımasız zulüm, aç- 
lık ve zorlama, işkence, sürekli korku ve çaresizlik gibi travmatizasyon türlerinin sonraki etkilerini ele almış ve kurbanların yaşadığı travmanın birçok durumda tanınabilir bir klinik varlık üretecek kadar ciddiyet ve süreye sahip göründüğünü belirlemiş̧tir. Niederland çalışmalarında, kurbanların yaşadığı bu trajediyi soykırım diye adlandırmanın yeterli olmadığını, soykırımdan geride kalanların çok daha uzun süre hayatların etkileyen bir psikolojik sendrom yaşadıkların ifade etmiş ve bunu da survivor sendromu ya da dilimize çevrilmiş hali ile geride kalanlar sendromu olarak adlandırmıştır. Niederland üç buçuk yılı aşkın süre boyunca 2000'e yakın toplama kampından geride kalan kurbanların değerlendirilmesi, teşhisi ve tedavisi sonucunda yaşa, cinsiyete ve bireysel veya sosyokültürel geçmişe bakılmaksızın gelişen geride kalanlar sendromunun hayatta kalanlar üzerindeki etkilerinin çok uzun yıllarca ve genellikle şiddetli bir şekilde devam ettiğini ortaya koymuştur (Niederland, 1981).

Konu üzerine yapılan araştırmalar, soykırımdan kurtulanlar arasında aynı olmasa da benzer psikolojik durumların olduğunu ortaya koymuştur. Buna göre çatışma, doğal afet, terörist saldırı, hava kazası ve işten çıkarma gibi çok çeşitli travmatik durumlardan kurtulanlarda benzer işaretler ve semptomlar görülmüştür. Tehlikede olanlara yardım etme konusunda çok az şey yaptıkları için kendilerini suçlayan kurtarma ve acil servis personeli arasında ve hastalarının acısı karşısında bir tür suçluluk hissedebilen terapistler arasında da benzer semptomlara rastlanmıştır. Geride kalan çalışanlar, artan iş yükleriyle, düşen morallerle, süregelen kaygılarla ve her şey için minnettar olmaları gerektiğine dair rahatsız edici duygu ile her gün yüzleşerek bir yandan da işlerini ellerinde tutmaya çalışmaktadır. Bu tarz travmatik durumlarda geride kalmak, bazen işten ayrılmak kadar üzücü olabilmektedir. Geride kalanlarında mağdur olduğu bu durumda, doğal afet veya korkunç bir kazada başkaları yaralanırken zarardan kaçan insanlar gibi, işlerini kaybetmeyen çalışanlar da kendilerini suçlu hissetmektedirler (Aleccia, 2008). Felaketin ya da yaşanılan işi kaybetme durumunun her an kendi başına da gelebileceğini ve kaderini kontrol edemeyeceğini düşünen çalışan, süregelen belirsizlik durumundan dolayı kendisini endişeli, depresif, öfkeli ve fiziksel olarak hasta hissedebilmektedir.

Survivor sendromunun işletmelere uyarlanmış hali olan geride kalanlar sendromu, örgütlerde işten çıkarma ya da işten ayrılmaların ardından ör- 
gütte çalışmaya devam edebilen ve yaşanan belirsizlik ortamında, geride kalan çalışanların, olumsuz duygular içerisine girmesi durumunu ifade etmektedir. Geride kalan sendromu olarak adlandırılan bu olumsuz ruh halinde çalışan; kızgınlık, endişe, korku duyma, güvensizlik, işini kaybetme korkusu, verimlilikte düşüş, suçluluk duygusu, depresyon, örgüte olan bağlllı̆̆ın azalması gibi belirtiler gösterebilmektedir (Frone ve Blais, 2020). Polonyalı işçiler üzerinde yapılan bir araştırmada, küçülme sonucunda işten çıkarılmaya maruz kalmayan (geride kalan) işçilerde yüksek düzeyde stres ve işten ayrilma niyetleri gözlemlenirken; iş tatmini, iş bağlllı̆̆1 ve iş performansının düşük seviyelerde olduğu gözlemlenmiştir (Widerszal-Bazyl ve Mockallo, 2015). ABD'li işçilerle ilgili büyük bir ulusal araştırma sonucunda ise geride kalanlarda örgütsel bağlılık ve algılanan performansta önemli ölçüde azalma, işten ayrılma niyetinde ise önemli ölçüde artış olduğu gözlemlenmiştir (Maertz, Wiley, LeRouge ve Campion, 2010). İslamoğlu ve Turgut (2003)'un işletmelerde küçülme ve survivor sendromu üzerine yapmış oldukları araştırmada ise, geride kalanlarda yüksek oranda iş güvensizliği, depresyon ve yorgunluk hissine rastlandığı ortaya konulmuştur.

Geride kalanlar sendromunun temel nedenleri arasında, gidenler (işten ayrılanlar) ile benzer özelliklere sahip olmak, geride kalan çalışanların kendilerine güvenlerinin zayıf olması, kriz döneminde uygulanan örgütsel politikalar, dış çevre, geride kalan çalışanın özel hayatı (bakmakla yükümlü olduğu insanlar olması), yeni bir iş bulma olasıllğı (yaş, deneyim, ekonomik imkansızlıklar gibi), çalışanın maddi durumu, iş doyumu, sosyal konum gibi faktörler bulunmaktadır. Ayrıca geride kalanlar sendromunu yoğun biçimde yaşayan çalışanlarda riskten kaçınma, başkalarını şikâyet etme, yöneticilere karşı kendini koruma gereksinimi ve inkâr etme eğiliminin meydana geldiği ifade edilmektedir (Özbey, 2010, s.50-51).

Brockner, Groveres ve Witt (1992)'e göre geride kalanlar sendromunun çoğunlukla gözlemlenen belirtileri endişe, korku, depresyon, üzüntü, suçluluk, kızgınlık, kariyer belirsizliğidir. Geride kalanlar sendromun işgörenler üzerindeki etkileri ise hastalığa yatkınlık, yorgunluk hissi, sürekli moral bozukluğu, çalışanların birbirlerine, yöneticilerine veya işverenlerine karşı güvenlerinin azalması şeklinde ortaya çıkmaktadır (Sahdev ve Vinnicombe, 1998). İşten çıkarma travmasının üstesinden gelmek ve küçülmeye giden işletmeleri yeniden canlandırmak üzerine önemli çalışmalarıyla bilinen Noer (2009) ise, geride kalanların yaşadıkları duygusal ve zihinsel olumsuzlukların 
haksızlık algısı, iş güvensizliği, depresyon, endişe ve bitkinlik hissi, motivasyonda azalma, güvensizlik ve ihanet, iletişimde bozulma, karşılıklı güven kaybı ve yönetimin güvenirliliğinin azalması gibi sonuçlara yol açacağını ortaya koymuştur. Artan iş yükü, süregelen belirsizlik, endişe ve korku, yıllardır birlikte çalışılan meslektaşların boş koltuklarıyla her gün yüzleşmek zorunda kalmak ve tüm bunlara rağmen hala bir işi olduğuna ve hasta olmadan hayatta kaldığına şükretmek zorunda olan sağlık çalışanlarının pandemi günlerinde yaşadıkları tam da bu geride kalanlar sendromunu ifade etmektedir. Sağlık çalışanlarının yaşadığı bu sendromun doğru ve planlı şekilde ele alınmaması ve çözüm üretilmemesi durumunda ilerde sağlık kurumları açısından çok daha olumsuz sonuçların oluşabileceği düşünülmektedir. Bu bağlamda bu çalışmada tüm dünyayı etkisi altına alan Covid-19 pandemisinin sağlık çalışanları üzerindeki psikolojik semptomu olduğu düşünülen geride kalanlar sendromunu ortaya koymak amaçlanmıştır.

11 Mart 2020' de Dünya Sağllk Örgütü tarafından küresel salgın (pandemi) olarak ilan edilen Covid-19 salgını sırasında bugüne kadar dünya çapında en az 7.000 sağlık çalışanının koronavirüs nedeniyle hayatını kaybettiği tahmin edilmektedir (Amnesty İnternational, 2020). Ülkemizde ise 4 Şubat 2021 itibari ile 366 sağlık çalışanının hayatını kaybettiği bilinmektedir (Türk Tabipleri Birliği, 2021). Sağlık Bakanı Fahrettin Koca, Koronavirüs Bilim Kurulu toplantısı sonrası yaptığı basın açılamasında ise Covid-19 testi pozitif çıkan sağlık çalışanı sayısının 40 bini aştığını ifade etmiştir (Koca, 2020). Rakamlar aslında sağlık çalışanları açısından travmanın ve trajedinin ne boyutlarda olduğunu ortaya koymaktadır. Her gün ölüm ve enfekte olma korkusuyla bu belirsizlik ortamında çalışmaya devam etmenin, insanların hayatını kurtarma görevini yerine getirmek zorunda olmanın ve tüm bunları yaparken birde ailevi ve ekonomik kaygılar taşımanın sağlık çalışanlarının psikolojilerini ne denli tahrip edeceği ortadadır. Böyle bir durumda hastalığa yakalanmadan ya da ölmeden işe devam eden sağlık çalışanlarının geride kalanlar sendromu yaşaması kaçınılmaz olmaktadır.

\section{Yöntem}

Nitel araştırma yöntemine göre tasarlanan bu araştırmada fenomenoloji deseni kullanılmıştır. Olgubilim olarak da adlandırılan fenomenoloji deseni farkında olduğumuz fakat ayrıntılı bir şekilde derinlemesine bir anlayışa sahip 
olmadığımız olgular üzerinde durmaktadır. Olgular, yaşadığımız dünyada olaylar, deneyimler, algılar, yönelimler, kavramlar ve durumlar gibi çeşitli biçimlerde karşımıza çıabilmektedir. Tamamen yabancı olmadığımız ancak bununla birlikte tam anlamını kavrayamadığımız olguları incelemeyi amaçlayan araştırmalar için olgubilim (fenomenoloji) uygun bir araştırma deseni oluşturmaktadır (Yıldırım ve Şimşek, 2016). Fenomenoloji "Gerçek nedir?" sorusuna cevap bulmaya çalışan bir araştırma desenidir. Fenomenolojik araştırma yaklaşımının özünü kişisel tecrübeler oluşturmaktadır. Fenomenolojik araştırmada araştırmacı katılımcının öznel tecrübeleri ile ilgilenmekte, bireyin algılamaları ve olaylara atfettikleri anlamları analiz etmektedir. Fenomenoloji tanımlayıcı bir araştırma desenidir. Dolayısıyla bu tür araştırmalarda genelleme yapmak değil, olguları tanımlamak önemli olmaktadır (Akturan ve Esen, 2008).

İnsanların sadece nasıl davrandıklarını değil, niçin öyle davrandıklarını anlayabilmek için fenomenolojik araştırmalara başvurulmaktadır. Bu araştırma yaklaşımında araştırmacı katılımcının bireysel deneyimleri ile ilgilenir, olay ve olgulara verdiği anlamları onun zihninden anlamaya ve yorumlamaya, gerçekliğin katılımcının zihninde nasıl yapılandığı ve inşa edildiğini anlamaya çalışmaktadır. Fenomenolojik araştırma bir konuyu aydınlatma, dikkat çekme, olay, durum, deneyim ya da kavramı incelemek amacıyla yapılabilmektedir. Bu araştırma deseni tıp, klinik psikoloji, sosyal psikoloji ve davranış bilimlerinin psikoloji, antropoloji, sosyoloji gibi diğer alanları için uygun bir analiz tekniğidir. Fenomenolojik araştırmaların temel amacı aslında insan deneyimini anlamlı hale getiren şeyin ne olduğunun araştırılmasidir (Tutar ve Erdem, 2020, s.200).

\section{Örneklem}

Nitel araştırmalarda büyük gruplar yerine, araştırmanın amacına uygun olan ve veri doygunluğunu sağlayacağı düşünülen kişilerle görüşülmesi tercih edilir. Bu bağlamda nitel araştırmalarda genellikle tesadüfi olmayan amaçlı örnekleme tekniği tercih edilir (Tutar ve Erdem, 2020, s.250). Burada kriter nicelik değil, katılımcıların niteliği ve konu hakkındaki bilgisidir. Ayrıca fenomenolojik araştırmalarda veri kaynakları araştırmanın odaklandığı olguyu yaşayan ve bu olguyu dışa vurabilecek veya yansitabilecek bireyler ya 
da gruplardan oluşmalıdır (Yıldırım ve Şimşek, 2016). Bu araştırmanın çalışma grubu, amaçlı örnekleme yöntemi ile belirlenmiştir. Katılımcılar kamu hastanelerinde doktor ve hemşire olarak görev yapan gönüllü kişilerden oluşmuştur. Nitel araştırmalarda örneklem büyüklüğü için temel kural, veri doyumuna ulaşmaktır. Örneklem birimlerinden yeni bilgi gelmediği, başka bir ifade ile yeni örneklem birimleri zaten var olan bilgileri tekrar etmeye başladığı zaman doyum noktasına ulaşılmış demektir (Baş ve Akturan, 2017:92). Bu çalışmada da mülakatlarda farklı bilgiler elde edildikçe araştırma yapılmaya devam edilmiştir. Çalışma pandemi sürecinde bir Üniversite Hastanesinde görev yapmakta olan 10 sağlık çalışanının görüşmeye katılımıyla gerçekleştirilmiştir. Katılımcılara ilişkin bilgiler Tablo 1.'de sunulmuştur.

\section{Veri Toplama Araci ve Verilerin Toplanması}

Bu çalışmada veri toplama aracı olarak araştırmacı tarafından geliştirilen yarı yapılandırılmış görüşme formu kullanılmıştır. Yarı yapılandırılmış görüşme formunun tercih edilmesinin sebebi, araştırmacılara genel hatlarıyla bir yol haritası çizmekle birlikte, katılımcıların ilgi, bilgi ve tecrübesine göre bu genel çerçeve içerisinde kalmak koşuluyla farklı sorular sorarak konunun değişik boyutlarını ortaya çıkarma olanağı tanımasıdır (Coşkun, Altunışık, Bayraktaroğlu ve Yıldırım, 2015). Görüşme formunun oluşturulması sürecinde alan yazın incelenerek sorulacak sorular belirlenmiş ve daha sonra alanında uzman olan üç bilim insanı ile sorular tartışılarak son şekli verilmiştir. Ayrıca nitel görüşme formunun anlaşılırlığını görmek için iki çalışan üzerinde pilot çalışma yapılmıştır. Pilot çalışma sonucunda görüşme formunun nitel verilerin toplanmasına uygun olduğuna karar verilmiştir. Yarı yapılandırılmış görüşme formu 10 sorudan oluşmaktadır. Görüşme tekniği, önceden belirlenmiş ve belli bir amaç için yapılan, soru sorma ve yanıtlama tarzına dayalı karşılıklı ve etkileşimli bir iletişim süreci olduğu için tercih edilmiştir (Yıldırım ve Şimşek, 2016, s.119). Ortalama görüşme süreleri 30£5 dakikadır.

Araştırma kapsamında "Pandemi sürecinde sağlık çalışanlarında geride kalanlar sendromu görülmekte midir?" temel sorusu çerçevesinde aşağıda verilen alt sorulara cevap aranmaktadır:

- Geride kalanlar sendromunun belirtileri nelerdir?

- Geride kalanlar sendromunun örgütsel açıdan olumsuz sonuçları nelerdir? 


\section{Verilerin Analizi}

Görüşmelerden toplanan veriler, nitel analiz tekniklerinden içerik analizi tekniği ile analiz edilmiştir. İçerik analizi "belirli kurallara dayalı kodlamalarla, bir metnin bazı sözcüklerinin daha küçük kavram, kod, kategori ve temaları şeklinde özetlendiği sistematik bir teknik" (Rubin ve Rubin, 1995, s.78; Mason, 2002, s.54; Patton, 2014, s.429; Büyüköztürk, Kılıç, Akgün, Karadeniz ve Demirel 2014, s.45; Creswell, 2016, s.179) olması nedeniyle bu araştırmanın amacına ve problemin çözümüne uygun olduğu gerekçesiyle tercih edilmiştir. Veri analizinde görüşme notlarındaki cümleler alt alta yazılarak, benzerlik ve farklılık gösteren ifadeler bir araya getirilmiş, daha sonra betimsel ifadelerden "kavram"lara, oradan "kod"lara, kodlar arasındaki benzerliklerden "kategoriler"e, daha sonra da anlam içeriğini yansitabilecek "ana tema"lara ulaşılmaya çalışılmıştır (Creswell, 2016, s.180).

\section{Bulgular}

Katılımcılara ilişkin demografik bilgiler Tablo 1.'de sunulmuştur.

Tablo 1. Katılımcılara İlişkin Demografik Bilgiler

\begin{tabular}{llll}
\hline Katılımc & Cinsiyet & Yaş & Görev \\
\hline K1 & Kadın & 36 & Hemşire \\
\hline K2 & Erkek & 41 & Hekim \\
\hline K3 & Kadın & 35 & Hemşire \\
\hline K4 & Erkek & 44 & Hekim \\
\hline K5 & Kadın & 32 & Hekim \\
\hline K6 & Kadın & 31 & Hemşire \\
\hline K7 & Erkek & 34 & Hekim \\
\hline K8 & Kadın & 30 & Hemşire \\
\hline K9 & Erkek & 42 & Hekim \\
\hline K10 & Erkek & 33 & Hekim \\
\hline
\end{tabular}

Yukarıdaki tabloda verilen katılımcılara ilişkin bilgiler incelendiğinde beş kadın ve beş erkek olmak üzere, dört hemşire ve beş adet hekimden oluşan bir örneklem olduğu görülmektedir. Katılımcıların yaşlarına bakıldığında 3045 yaş aralı̆̆ında oldukları görülmektedir.

Katılımcılara geride kalanlar sendromunun belirtilerini görebilmek için ilk olarak enfekte ya da ölüm nedeniyle pandemi sürecinde yaşanan işten ayrılmalardan dolayı kendilerini nasıl hissettiklerini ve bu durumdan nasıl etkilendiklerini anlamaya yönelik sorular sorulmuştur. Katılımcı görüşleri ve 
içerik analizi sonucunda ulaşılan kodlar, kategoriler ve ana temalar aşağıda Tablo 2.'de sunulmuştur.

Tablo 2. Geride Kalanlar Sendromunun Belirtileri

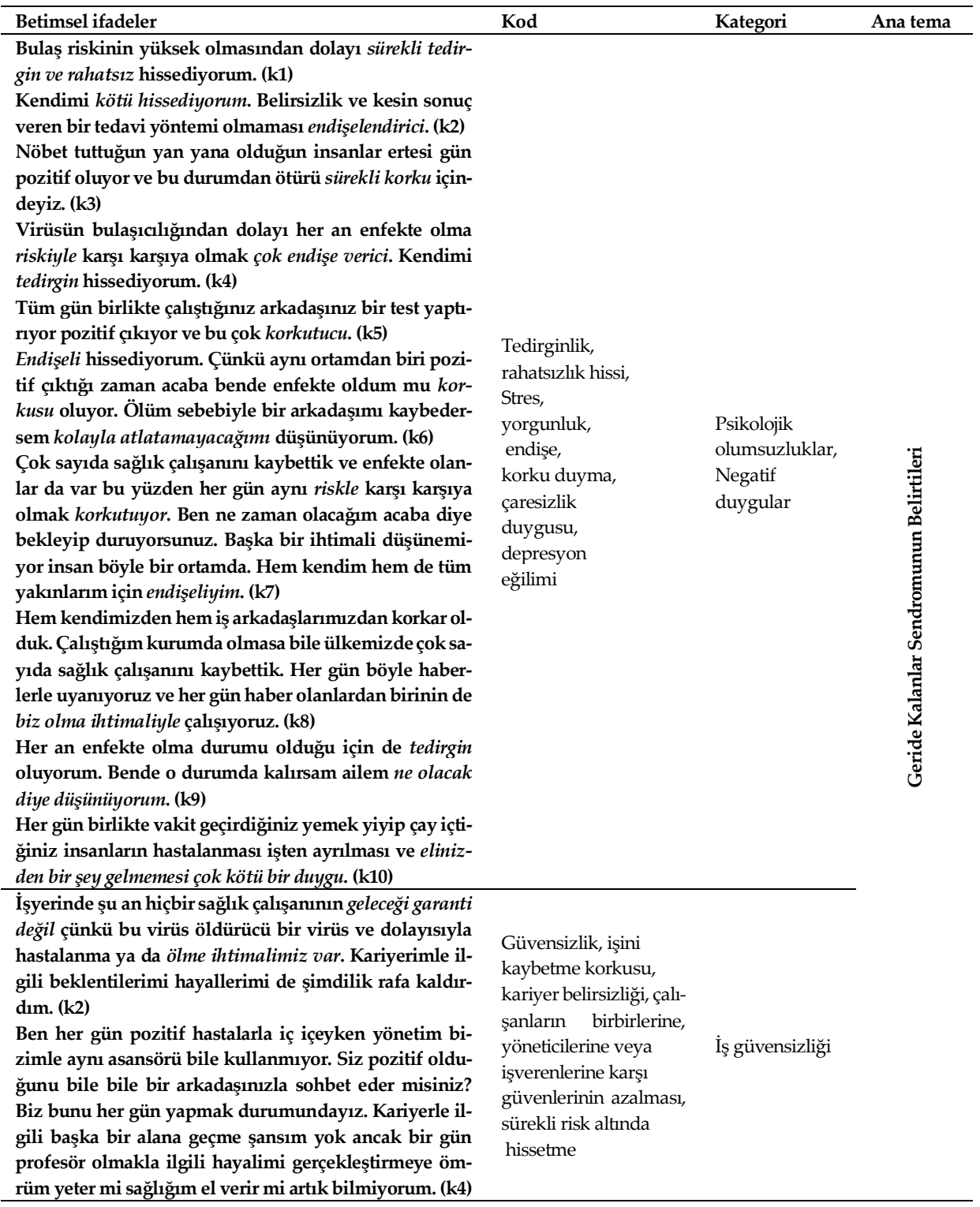


Yönetime ve işyerine karşı güvenim yok. Bu süreçte herkes kendini düşünüyor. Bu bilinmezlik yarnn ne olacağgnın belirsizliği ve söz konusu ihtimalin ölüm-yaşam çizgisinde olması sizce de çok korkunç değil mi. (k6)

Bu süreç bizi fizikselden çok mental olarak tüketti. Bu hastalığın sonuç veren bir aşısı veya kesin bir tedavisi olmaması bu belirsizlik içinde işe devam etmek gibi faktörlerden dolayı ruhsal olarak zorlanıyoruz. (k10) Nöbet çıkışları özellikle sürekli geçmeyen baş ağrısı ve ayak ağrısı hissediyorum. (k3)

Bizim gibi sahada görev alan yaşanan sıkıntılara birebir şahit olan sağlık çalışanlarının psikolojisinin ve zihin-

Verimlilikte düşüş, işi eskisi gibi yapamama İş performansinda düşüş sel yorgunluğunun uzun süre atlatılabileceğini düşünmüyorum. (k5)

Özellikle çalıştığım kuruma karşı işe gitme isteğimi kaybettim. (k3)

Isse gitme isteğim azaldı. Dediğim gibi siz kendi ayağınızla pozitif biriyle buluşmaya gidermişiniz? İşinizi ne kadar severseniz sevin bu virüsün henüz kesin sonuç veren bir aşısı ve tedavisi olmaması, yarattığı kaygı ve stres çalışma isteğinizi azaltıyor. (k2)

Çalışma isteğim azald çünkü pandemi servisindeyim uzun zamandır izin yapmıyoruz insan üstü bir gayret göstermemiz gerekiyor bu da işyerine giderken isteksiz olmama yol açıyor. (k5)

Bu mesleği isteyerek seçen biri olarak beni bile soğuttu meslekten. Her gün yüksek riskle karşı karşıya olmak ve normal rutin işinize göre sorumluluğunuzun fazla olması çalışma isteği bırakmıyor. (k8)

Ömür boyu bu işi yapabilecek tahammülüm kaldığın düşünmüyorum. Ben şu pandemiyi yaşadıktan sonra maddi imkânı olup hala bu işi yapmak isteyen olacağını sanmiyorum. (k10)

Şu an gencim ve bekarım ama ileriki yaşlarda olsam ve bir ailem ve çocuklarım olsa kesinlikle bu işi yapmak benim için daha zor olabilirdi. İmkân olursa kendi işimi yapabileceğim bir şeyler düşüneceğim. (k8)

Çoğu kez işten ayrılmayı düşünnüyorum. Artık sağlık sektöründe bir kariyer istemek çok idealistlik olur. Bugün işten ayrilmak isterim ama maddi imkansızlıklar elvermiyor. (k6)

Hastalığa yakın zamanda bir tedavi bulunmazsa benim gibi işini severek yapanlar için bile $b u$ iş artık maddi kaygılar dışında yapılabilecek ve sevilebilecek bir iş olmaktan çıkar. (k2)

Kesinlikle bir ömür boyu nöbet tutan bir hemşire olarak kalmamalıyım. Bu tempoya bundan 10 yıl sonra katlanamam. (k3)

Ömür boyu bu işi yapacak enerjiye cesarete ve psikolojik dayanıklılığa sahip olabileceğimi düşünmüyorum. Uzmanlığımı bir an önce alıp kamudan ayrılmayı planlıyorum artık. (k5)

Aidiyet hissi sorunu, Örgütsel işe karşı isteksizlik, bağlılığın işten soğuma azalması
İş değiştirme isteği, işten ayrılma isteği, işe karşı tahammülsüzlük
İşten ayrılma

niyetinin

artması 
Yukarıdaki tabloda sunulan katılımcı görüşleri incelendiğinde pandemi sürecinde ölüm veya enfekte olma sebebiyle yaşanan işten ayrilmalardan sonra katılımcların tedirgin ve endişeli hissettikleri, korku duydukları ve bundan dolayı sürekli olumsuz duygular içinde oldukları, yöneticilere güvenlerinin azaldığı, kariyerlerinin belirsiz ve risk altında olduğu; bundan dolayı iş güvensizliği yaşadıkları, işi eskisi gibi yapamadıkları, işe karşı isteksiz olmaları dolayısıyla örgüte bağlılığın azaldığı ve işten ayrılma niyetinin arttığ1 yönündeki görüşleri geride kalanlar sendromunun belirtileri ana teması altında toplanmıştır. Konuyla ilgili katılımclara ait betimsel ifadelerden bazıları şunlardır:

- “Her gün gördü̆̆̈̈nüz tanıdığınız hayatında onca ana şahit olduğunuz birinin, tedavisi olmayan bir hastalıktan dolayı kaybedilmesi, üstelikte bu hastalığı görevi sırasında kapmış olması, çalıştığı yerin ona mezar olması kelimelerle çok anlatılabilir bir durum değil. Uzun yillar geçse de bu kurumda unutulmayacaktır." K5

- "Kuvvetli bir ihtimal işten ayrilacak bir sonraki kişi ben olacağım çünkü çoğu çalışma arkadaşım bu hastalı̆̆ atlattı benim gibi henüz enfekte olmayan çok az. O yüzden sıramı bekliyorum. Çaresiz hissediyorum. Tedirginim çünkü ağır mı geçireceğim hafif mi atlatacağım bilmiyorum." K6

- "Biz bir savaş veriyoruz ve cephenin en önündeyiz. Kendim için olmasa da ailem ve sevdiklerim için korku duyarken bir yandan size ihtiyacı olan hastalara bakmak için işinizi yapmak durumundasını yardım etmek istiyorsunuz. Çok tuhaf duygular." K4

- "Bu süreç bizi fizikselden çok mental olarak tüketti. Bu hastahğin sonuç veren bir aşısı veya bir tedavisi olmaması bu belirsizlik içinde işe devam etmek gibi faktörlerden dolayı ruhsal olarak değiş̧tik. Ben şu pandemiyi yaşadıktan sonra maddi imkânı olup hala bu işi yapmak isteyen olacağıı sanmıyorum." K10

- "Enfekte olan hemşire arkadaşların sayısı en az \%30 luk kısım. Nöbet tuttuğun yan yana olduğun insanlar ertesi gün pozitif oluyor ve bu durumdan ötürü sürekli korku içindeyiz." K3

Yukarıda verilen betimsel ifadelerden anlaşıldığı üzere katılımcıların en fazla vurgu yaptıkları korku, endişe, sürekli risk altında hissetme, tedirginlik, çaresizlik gibi psikolojik olumsuzluklar pandemi sürecinde katılımcıların geride kalanlar sendromunu yoğun bir şekilde yaşadıklarını ortaya koymaktadir. 
Tablo 3. Geride Kalanlar Sendromunun Sonuçları

\begin{tabular}{|c|c|c|c|}
\hline Betimsel ifadeler & Kod & Kategori & $\begin{array}{l}\text { Ana } \\
\text { tema }\end{array}$ \\
\hline
\end{tabular}

ğın sonuç veren bir aşısı veya kesin bir tedavisi olmaması bu belirsizlik içinde işe devam etmek gibi faktörlerden dolayı ruhsal olarak zorlantyoruz. (k10)

Çalışma süremiz ve izinlerimiz bir insanın verimli bir şekilde ve motivasyonu yüksek bir şekilde çalışmasına imkân vermiyor. (k2)

Sahada çoğu arkadaşımız tükendi ve yorgun. (k4)

İş yükümüz arttı ve bundan dolayı kendimi bitkin yorgun kırgın hissediyorum ve çoğu zaman başım ağrıyor. (k5)

Mesai saatleri uzadığı için ve maskeyle çalışmak insanı fena halde zorladığı için kendimi sürekli bitkin hissediyorum. (k6) Çoğu zaman yorgun ve bitkinim. Çalışma enerjisi heyecanı ya da mesleki bir bağlılığım kalmadı. (k7)

Pandemi sürecindeki belirsizlik zaman zaman motivasyonumuzu kaybetmemize sebep oldu ve hastalıktan dolayı işten ayrılan arkadaşlarımızın durumu moralimi çok etkiledi. (k1) Pandemi servisindeyim uzun zamandır izin yapmiyoruz insan üstü bir gayret göstermemiz gerekiyor bu da motivasyonumu düşürüyor. Özellikle yoğun bakımdakilerin entübe olanların nefes almakta zorlanışlarını gördüğünüz zaman benim gibi duygusal bir insansanız çok etkileniyorsunuz. (k5) Her gün bir yerlerde sağlık çalışanlarının öldüğü haberlerini alıyoruz ve bundan dolayı moralimiz bozuk. (k6) Bu belirsizlik ve kesin bir tedavisi olmayışı her gün aklımızda en kötü ihtimallerle işe gitmeye neden oluyor. (k8)

Görevlerin dağıtımında adaletsizlik yapıldığını düşünüyorum. Bu durumdan etkilenmeyen idare kısmı işin içine girmeyen kısım unutacak ama bizler bunu bir süre daha psikolojik olarak atlatamayacağız. (k2)

Görev ve sorumluluk dağılımı her personelin üstünde eşit şekilde dağılmıyor. Astlar her yerde olduğu gibi burada da en fazla risk altında kalanlar oluyor. (k4)

Yük herkesin omzuna eşit olarak dağılmıyor bundan dolayı

Tükenmişlik

hissi,

işi yaparken

ruhsal

olarak zor-

İşyerinde

lanma,

verimsizlik

endişe, yorgun-

luk ve bitkinlik

hissi

Moral bozuk-

luğu,

motivasyon dü- Motivas-

şüklüğü,

karamsarlık

yon

kaybi

güvensizlik

adaletsizlik

Örgütsel

adalet

algisının

zayıflaması

İletişimde

bozulma,

çalışma

arkadaşlarıyla

eskisi

Örgütsel

gibi iletişim

kuramama, yö-

iletişimin

zayıflaması

şimde

problemler yor. (k7)

Yönetim personelle birebir iletişim kurmuyor. Herkesin kendi canı kıymetli. (k10) 
Pozitif vakaların olduğu serviste işler nasıl yürüyor diye yöne-

timden bir kere bile gelip bakan olmadı. (k3)

Yönetimin bu süreçte bizi dïşünen hiçbir hareketleri olmadı yapılan düzenlemeler empatiden yoksun bir anlayışla yapıldı. İşler nasıl yapılıyor diye düşünüp bir kere alana gelip bir sıkıntınız var mı diye soran bir yönetici göremedik. (k1)

Yöneticilerin servislere girdiği yok. Sağlık çalışanları için alınan tedbir koruyucu giysi ve maskeden ibaret. Pozitif vakalarla her gün burun buruna olan biziz. Burada hiçbirimiz gïvende değiliz zaten. (k2)

Yönetimdekiler riskten uzak bir şekilde hayatlarına devam ederken bizler her gün sahada pozitif vakalarla iç içeyiz. Yöne-

Karşılıklı güven kaybı ve yönetimin güvenirliliğinin azalması
Örgütsel

güvenin zayıflaması

time güvenim olumsuz yönde etkilendi. (k5)

Yöneticiler bizimle aynı koridoru kullanmaktan bile kaçınıyorlar. (k6)

İş memnuniyetimiz ile ilgili yönetimden bizim sıkıntılarımızı

dinlemek isteyen kimse olmadı. (k7)

Yukarıda Tablo 3'te katılımcların pandemi sürecinde tükenmiş hissettikleri, işyerinde verimsiz oldukları, moral bozukluğu yaşadıkları, motivasyonlarını kaybettikleri, görev dağılımındaki haksızlıklardan dolayı örgütsel adalet algılarının zayıfladığı, çalışma arkadaşlarıyla ve yöneticilerle iletişimlerinin azalması dolayısıyla örgütsel iletişimin zayıfladığı, özellikle yönetimin güvenilirliğinin azalmasından dolayı örgütsel güvenin zayıfladığı yönündeki görüşleri geride kalanlar sendromunun sonuçları ana teması altında toplanmıştır. Konuyla ilgili bazı katılımcılara ait betimsel ifadeler aşağıda sunulmuştur:

- "Pandemide olan sahada çalışan sağlık çalışanlarnna oldu. Yöneticilerin servislere girdiği yok. Sağllk çalışanlar için alınan tedbir koruyucu giysi ve maskeden ibaret. Pozitif vakalarla her gün burun buruna olan biziz. Burada hiçbirimiz güvende değiliz zaten." K2

- "Yönetim hastalarla birebir muhatap olmuyor pozitifvakalarla her gün iç içe olan bizleriz. Tabiki bu bizim işimiz ama göstermelikte olsa ara strada olsa keşke yanmızda olduklarmı bilsek. Yönetim personelle birebir iletişim kurmuyor. Herkesin kendi canı kıymetli." K10

- "Siz kendi ayă̆ınıla pozitifbiriyle buluşmaya gidermişiniz? Biz her gün pozitif hastalarla bir aradayız. Sahada aylardır izin yapmadan çalışan arkadaşlar var. İsinizi ne kadar severseniz sevin bu virüsün henüz olumlu sonuç veren bir aşısı ve tedavisi olmaması, yarattı̆̆ı kaygl ve stres çalışma isteğinizi azaltıyor." K3 
- "Bu süreçte yönetimin bizi düşünen hiçbir hareketleri olmadı yapılan düzenlemeler empatiden yoksun bir anlayışla yapıldı. İşler nasıl yapılıyor diye düşünüp bir kere alana gelip bir sıkıntınız var mı diye soran bir yönetici göremedik." K1

Katılımcı ifadelerinden anlaşıldığ 1 üzere geride kalanlar sendromu sağlık çalışanlarında en yoğun olarak yöneticilerle iletişimin bozulması ve yöneticilere olan güvenin azalmasıyla sonuçlanmıştır. Ayrıca çalışanların yöneticilere olan bu güvensizliği görev ve sorumlulukların dağıtımında adaletsizlik yapıldığı konusundaki algılarını da yükseltmiş ve bu da örgütsel adalet algısının zayıflamasına neden olmuştur.

\section{Tartışma ve Sonuç}

Geride kalanlar sendromu en genel ifade ile kriz dönemlerinde ölüm, enfeksiyon, ekonomik yetersizlikler gibi nedenlerden dolayı yaşanan işten ayrılmalar sonrasında çalışmaya devam eden (geride kalan) çalışanlarda görülen ve etkisi uzun süre devam eden karmaşık davranışlar ve duygulardır. Bu çalışmada tüm dünyayı etkisi altına alan COVID-19 pandemisinde sağlık çalışanlarının yaşamış olduğu geride kalanlar sendromunu ortaya koymak amaçlanmıştır. Araştırma bulgularına göre sağlık çalışanları pandemi sürecinde yoğun bir şekilde geride kalanlar sendromu yaşamaktadırlar. Buna göre geride kalanlar sendromunun sağlık çalışanlarında en yoğun gözlemlenen belirtilerinin tedirginlik, korku, endişe, karamsarlık gibi olumsuz duygular ve işini kaybetme korkusu, kariyer geleceğinin belirsizliği, çalışanların birbirlerine, yöneticilerine veya kuruma karşı güvenlerinin azalması, sürekli risk altında hissetme gibi durumlardan dolayı iş güvensizliği yaşamaları olduğu tespit edilmiştir. Sağ lık çalışanları pandemi döneminde fiziksel yorgunluktan çok mental olarak yorulduklarını vurgulamışlar ve yaşanan bu psikolojik olumsuzluklardan dolayı işyerinde verimsizlik yaşandığı anlaşılmıştır. Sağlık çalışanlarının bu süreçte işyerine gitmekte isteksiz olduklarını sıklıkla ifade etmeleri örgütsel bağlllığın azaldığının göstergesidir. Örgütsel bağlılığın azalmasına paralel olarak katılımcıların iş değiştirme ya da bu işi yapmama yönündeki görüşleri işten ayrılma niyetinin arttığını ortaya koymuştur.

Bu araştırmanın sonuçlarına göre geride kalanlar sendromunun en dikkat çekici sonuçları örgütsel iletişimin ve örgütsel adalet algısının azalmasıdır. 
Sağlık çalışanları en sık olarak yöneticilerle iletişimin bozulduğunu ve yöneticilere olan güvenlerinin azaldığını, görev ve sorumlulukların dağıtımında adaletsizlik yapıldığını düşündüklerini ifade etmişlerdir. Pandemi sürecinde yaşanan karşılıklı güven kaybı ve yönetimin güvenirliliğinin azalması örgütsel güvenin azalmasına da neden olmuştur. Ayrıca çalışanların bu süreçte ölüm ya da enfekte olma nedeniyle kaybedilen iş arkadaşlarından dolayı sürekli risk altında hissetmeleri karamsarlığa, moral ve motivasyon kaybına neden olmuş ve tüm bunlar işyerinde verimsizlikle sonuçlanmıştır. Görüldüğü üzere geride kalanlar sendromu aslında sağlık çalışanlarının farkında olduğu fakat üzerinde durulmayan bir psikolojik olumsuzluk hali olarak düşünülse de örgütsel açıdan faturası çok ağır olmaktadır. Literatürde işletmelerde geride kalanlar sendromu ile ilgili yapmış olduğu araştırmaları ile öne çıkan Noer (2009)'in çalışmasına göre de bu araştırmanın sonuçlarına paralel bir şekilde, geride kalan çalışanlarda iş güvensizliği, korku, endişe ve bitkinlik, algılanan adaletin zayıflaması, motivasyon kaybı, örgüte bağlılığın azalması, iletişim eksikliği, yönetime karşı güvenin azalması, işi eskisi gibi yapamamadan dolayı işyerinde verimliliğin azalması gibi sonuçları olmaktadır.

Konuyla ilgili olarak Demir (2010)' in yapmış olduğu araştırma sonucunda da bu çalışmanın sonuçlarına benzer şekilde geride kalan çalışanlarda yüksek oranda yorgunluk ve bitkinlik hissi görüldüğü ve işten çlkarılacak bir sonraki kişinin kendileri olabileceği konusunda sürekli endişeli oldukları ortaya konulmuştur. Sweeney ve Quirin (2009)' in çalışmasına göre ise geride kalan çalışanlarda iş stresinin ve iş güvensizliğinin görüldüğü ve bunlarında iş tatmini, işe bağlılık ve işten ayrılma niyetini doğrudan etkilediği ifade edilmiştir. Araştırma sonuçlarına göre geride kalanlarda artan iş stresi ve iş güvensizliği duygusal bağlılığı azaltmakta ve işten ayrılma niyetini artırmaktadır. $\mathrm{Bu}$ araştırmanın sonucunda da benzer şekilde geride kalan çalışanlarda pandemi ortamında yaşanan belirsizlikten dolayı iş stresi ve iş güvensizliğinin arttı̆ı ve çalışanların bir kısmında işten ayrılma niyetinin arttığ1 görülmüştür. Yöney (2010) örgütsel adalet ve örgütsel bağlllık ilişkisinde geride kalanlar sendromunun rolünü incelediği araştırmasında geride kalanların örgütsel adalet algılarının olumsuz etkilenmesi sonucunda örgütsel bağlılığın azaldığı sonucuna ulaşmıştır. Söz konusu araştırmanın bir diğer sonucu ise geride kalanların yöneticiler ile ilişkilerinin zayıflı̆̆ının örgütsel bağlllı̆̆ı olumsuz etkilediğidir. Bu araştırma da benzer şekilde geride kalanların yöneticileri ile 
ilişkilerinin zayıflığına sıklıkla vurgu yaptıkları ve yöneticilere güvenlerinin azaldığı tespit edilmiştir.

Araştırma sonuçlarından anlaşıldığı üzere pandemi sürecinde sağlık çalışanlarının yaşadığı geride kalanlar sendromu sağlık kurumlarında örgütsel iletişimin zayıflamasına da neden olmuştur. Salgında bulaş riskinin çok yüksek olması, sağlık kurumlarında çalışan personeli ve yönetimi bir araya getirme, sorunlara ortak bir paydada buluşarak çözüm bulma, öngörülebilir bir gelecek planı belirleme, karar verme ve çatışmalara çözüm üretme konularında sorunlar yaratmaktadır. Geride kalan çalışanların yaşadığı bu sendromun işletmeye bağlılı̆̆ın azalması ve performans düşüklüğü gibi biçimlerde görülebileceği ifade edilmektedir (Demir, 2010, s.185). Geride kalan çalışanların örgütsel bağlllıklarının devam edebilmesi ve yeniden motive olmuş bir şekilde çalışabilmeleri için işletmelerine güvenmeleri ve açık iletişim kurabilmeleri gerekmektedir. Bu süreçte geride kalan çalışanların en önemli ihtiyacını öncelikli olarak yöneticilerinin kendileri ile etkili bir iletişim kurarak, yönetimin çalışanların yanında olduğunun hissettirilerek örgütte güven ortamının oluşturulması ve çalışanların görev-sorumluluk dağılımının, onlarında ihtiyaç, istek ve kapasitelerinin dikkate alınarak belirlenmesi olduğu ortadadır. Bu hususta yapılacak planlı çalışmalar ve alınacak tedbirlerle örgütün geride kalan çalışanlara verdiği değeri göstermesi mümkün olacaktır. Bu şekilde çalışanların yönetime ve örgüte olan güvenlerinin sarsılması engellenebilir. Oluşturulan güven ortamı ve etkin bir iletişim hem çalışanların psikolojik iyilik halini hem de örgütsel sağlığın olumlu etkilenmesine katkıda bulunacaktır.

Gelecek araştırmacılara öneri olarak geride kalanlar sendromu ve örgütsel bağllıı arasındaki ilişki analiz edilebilir. Algılanan örgütsel adalet ile geride kalanlar sendromu arasındaki ilişki incelenebilir. Bu araştırma sağlık çalışanlarından oluşan bir örneklem ile sınırlıdır. Araştırma farklı örneklemler üzerinde tekrarlanabilir. Konu ile ilgili olarak karma araştırma yöntemine dayalı çalışmalar yapılabilir. 


\title{
EXTENDED ABSTRACT
}

\section{Survivor Syndrome in Pandemic Days: A Study on Health Workers}

\author{
Sevilay Güler \\ Independent Researcher
}

Survivor syndrome is a mental condition that occurs when a person feels guilty when surviving a traumatic or tragic event and believes that he or she has done something wrong that others did not. Survivor syndrome is observed in survivors from traumatic situations such as conflict, natural disasters, terrorist attacks, air accidents and a wide variety of layoffs; It refers to a psychological syndrome caused by negative emotions such as worry, anxiety, fear, and panic (Doherty and Horsted, 1995). Survivor syndrome, which is an adapted version of the business, refers to the situation of employees who are able to continue working in the organization after dismissal or leaving the organization and who are left behind in the uncertain environment, feel negative emotions. Working in this negative mood, which is called the remainder syndrome; workers may show symptoms such as anger, anxiety, fear, insecurity, fear of losing their job, decreased productivity, guilt, depression, and decreased commitment to the organization (Frone and Blais, 2020).

Increasing workload, ongoing uncertainty, anxiety and fear, having to face every day with the empty seats of colleagues who have worked together for years, and still be grateful that they still have a job and survive without being sick, express this precisely the survivor syndrome that healthcare professionals experience during the pandemic days. It is thought that if this syndrome experienced by healthcare workers is not addressed in a correct and planned way and a solution is not produced, much more negative consequences may occur for health institutions in the future.

During the Covid-19 pandemic, which was declared as a global pandemic by the World Health Organization on March 11, 2020, it is estimated that at least 7,000 healthcare workers worldwide have died due to the coronavirus (Amnesty International, 2020). In our country, it is known that 366 healthcare workers have lost their lives as of February 4, 2021 (Turkish Medical Association, 2021). Minister of Health Fahrettin Koca stated in a press release after 
the Coronavirus Scientific Committee meeting that the number of healthcare professionals who tested positive for Covid-19 exceeded 40 thousand (Koca, 2020). It is obvious that continuing to work in this environment of uncertainty with the fear of death and infection every day, having to fulfill the duty of saving people's lives, and having family and economic concerns while doing all of these will damage the psychology of healthcare professionals. In this context, this study aims to reveal the survivors syndrome, which is thought to be the psychological symptom of the Covid-19 pandemic on healthcare workers.

Phenomenology design was used in the study, which was designed according to the qualitative research method in line with the stated purpose. The main purpose of phenomenological research is to investigate what makes human experience meaningful (Tutar and Erdem, 2020, p. 200). In addition, data sources in phenomenological research should consist of individuals or groups who experience the phenomenon that the research focuses on and can express or reflect this phenomenon (Yıldırım \& Şimşek, 2016). In this context, the research was conducted with the participation of 10 healthcare professionals working in a University Hospital during the pandemic process. The semi-structured interview form developed by the researcher was used as the data collection tool. Collected data were analyzed using content analysis technique.

According to the findings of the research, healthcare workers experience the syndrome of survivors intensely during the pandemic process. According to this, the most intense symptoms of survivors syndrome in healthcare workers are negative emotions such as anxiety, fear, anxiety, pessimism and fear of losing their job, uncertainty of the career future, decreased trust of employees towards each other, their managers or the institution, and feeling occupational insecurity due to situations such as constantly feeling at risk. It has been determined that. Health workers emphasized that they were mentally tired rather than physical fatigue during the pandemic period, and it was understood that there was inefficiency in the workplace due to these psychological negativities. The fact that healthcare professionals frequently express that they are reluctant to go to the workplace during this process is an indication of a decrease in organizational commitment. 
According to the results of this study, the most striking results of the laggards syndrome are the decrease in organizational communication and organizational justice perception. Healthcare professionals most frequently stated that they thought that communication with managers was impaired, their trust in managers decreased, and that there was injustice in the distribution of duties and responsibilities. The loss of mutual trust and the decrease in the reliability of the management during the pandemic process also led to a decrease in organizational trust. In addition, the fact that the employees felt constantly at risk due to the loss of their colleagues due to death or infection during this process caused pessimism, loss of morale and motivation, and all of these resulted in inefficiency in the workplace.

As can be understood from the results of the research, the survivors syndrome experienced by healthcare workers during the pandemic process has also caused the weakening of organizational communication in health institutions. The high risk of transmission in the epidemic creates problems in bringing together the personnel and management working in health institutions, finding solutions to problems by meeting on a common ground, determining a predictable future plan, making decisions and producing solutions to conflicts. It is obvious that the most important need of the employees who are left behind in this process is to establish an atmosphere of trust in the organization by establishing an effective communication with the managers, making the management feel that they are with the employees, and determining the distribution of duties and responsibilities of the employees, taking into account their needs, wishes and capacities. In this way, the employees' trust in the management and the organization can be prevented from being shaken. An atmosphere of trust and effective communication will contribute to positively affect both the psychological well-being of the employees and the organizational health.

\section{Kaynakça / References}

Akcan, F. A., Onec, K., Annakkaya, A., Pehlivan, M., Karaduman, Z., Balbay, Ö., Demircan Çakar, N., ... , Koku, S. (2020). Pandemi sürecinde Düzce Üniversitesi Hastanesi: Başhekimlik yönünden. Konuralp Tip Dergisi, 12(1), 354-357.

Akturan, U. ve Esen, A. (2008). Fenomenoloji. T. Baş ve U. Akturan (Ed.), Nitel araştırma yöntemleri içinde (s. 83-98). Ankara: Seçkin Yayıncllk. 
Aleccia, J. (2008). Guilty and stressed, layoff survivors suffer, too. 2 Aralik 2020 tarihinde https://www.nbcnews.com/health/health-news/guilty-stressed-layoff-survivors-suffer-too-flna1C9455646 adresinden erişildi.

Amnesty International (2020). Global: Amnesty analysis reveals over 7,000 health workers have died from COVID-19. 4 Aralı 2020 tarihinde https://www.amnesty.org/en/latest/news/2020/09/amnesty-analysis-7000-health-workers-havedied-from-covid19/adresinden erişildi.

Baş, T., ve Akturan, U. (2017). Nitel araştırma yöntemleri. Ankara: Seçkin Yayınalık.

Bonnie S. F. ve Steven P. L. (2010). Encyclopedia of victimology and crime prevention. Thousand Oaks: SAGE.

Brockner, J.; Groveres, R. ve Witt, R.I. (1992). Layoffs, job insecurity, and survivors' work effort: Evidence of an inverted-U relation-ship. Academy of Management Journal, 35(1), 413-425.

Büyüköztürk, Ş., Kılıç Çakmak, E., Akgün, Ö.E., Karadeniz, Ş. ve Demirel, F. (2014). Bilimsel araştırma yöntemleri (17. bs.). Ankara: Pegem Yayınları.

Coşkun, R., Altunışık, R., Bayraktaroğlu, S. ve Yıldırım, E. (2015). Sosyal bilimlerde araştırma yöntemleri. Sakarya: Sakarya Yayınclik.

Creswell, J. W. (2016). Nitel araştırma yöntemleri beş yaklaşıma göre nitel araştırma ve araştırma deseni. (M. Bütün ve S. B. Demir, Çev.). Ankara: Siyasal.

Demir, N. (2010). Küçülmeye giden işletmelerde geride kalanların yaşadıkları tükenme sendromunun örgüte bağlllık üzerindeki etkisi. Öneri Dergisi, 9(33), 185-198.

Doherty, N., ve Horsted, J. (1995). Helping survivors to stay on board. People Management, 1(1), 26-31.

Frone, M. R. ve Blais A. (2020). Organizational downsizing, work conditions, and employee outcomes: identifying targets for workplace intervention among survivors. International Journal of Environmantal Reearch and Public Health, 17(719), 122.

Gemlik, N., Önal, G. ve Taşdemir, M. (2011). Örgütsel küçülme yaşayan bireylerin statüleri ile işten çkarılma korkuları arasındaki ilişkinin analizi ve medikal cihaz üreten işletmeler üzerine uygulama. Hitit Üniversitesi Sosyal Bilimler Enstitüsü Dergisi, 4(1), 43- 62.

İslamoğlu, G. ve Turgut, T. (2003). Downsizing practices and survivor syndrome. Quaderni Di Psicologia Del Lavoro: Identity and Organizations, 2(1), 163-170.

Koca, F. (2020). Koronavirüs bilim kurulu toplantısı basın açıklaması. 4 Aralık 2020 tarihinde https://www.evrensel.net/haber/416516/fahrettin-koca-testi-pozitif-olan-saglik-calisani-sayisi-40-bini-gecti adresinden erişildi. 
Lebovic, M. (2020). The only novel written at Auschwitz is finally to be published in English. The Times of Israel. 3 Aralık 2020 tarihinde https://www.timesofisrael.com/the-only-novel-written-at-auschwitz-is-finally-to-be-published-inenglish/adresinden erişildi.

Maertz, C.P., Wiley, J.W., LeRouge, C. ve Campion, M.A. (2010). Downsizing effects on survivors: Layoffs, offshoring, and outsourcing. Industrial Relations, 49(2), 275285.

Mason J. (2002). Qualitative researching. London: SAGE.

Niederland, W. G. (1981). The survivor syndrome: Further observations and dimensions. Journal of the American Psychoanalytic Association, 29(2), 413-25.

Noer, D. (2009). Healing the wounds: Overcoming the trauma of layoffs and revitalizing downsized organizations. Hoboken: Jossey Bass.

Özbey, S. N. (2010). Örgütsel küçülme, geride kalanlar sendromu veörgütsel bağhllı arasındaki ilişki. Yayımlanmamış Yüksek Lisans Tezi, Marmara Üniversitesi, İstanbul.

Patton, M. Q. (2014). Nitel araştırma ve değerlendirme yöntemleri. (M. Bütün ve S. B. Demir Çev.). Ankara: Pegem Akademi.

Rubin, H. ve Rubin, I. (1995). Qualitative interviewing: The art of hearing data. Thousand Oaks: SAGE.

Ryn, Z. (1990). The evolution of mental disturbances in the concentration camp syndrome (KZ-syndrom). Genetic, Social, and General Psychology Monographs, 116(1), 21-36.

Sahdev, K. ve Vinnicombe, S. (1998). Downsizing and survivor syndrome A study of HR's perception of survivors' responses. Human Resource Management Review, 3(1), 187-199.

Sweeney, J.T. ve Quirin, J. (2009). Accountants as layoff survivors: A research note. Accounting, Organizations and Society, 34, 787-795.

Dünya Sağlık Örgütü [WHO] (2010). What is a pandemic? 28 Ocak 2021 tarihinde https://www.who.int/csr/disease/swineflu/frequently asked questions/pandemic/en/ adresinden erişildi.

Widerszal-Bazyl, M. ve Mockallo, Z. (2015). Do all types of restructuring threaten employees' well-being? An exploratory study. International journal of occupational medicine and environmental health, 28(4), 689-706.

Tutar, H. ve Erdem, A. T. (2020). Bilimsel araştırma yöntemleri ve SPSS uygulamalan, Ankara: Seçkin Yayınclık.

Türk Tabipleri Birliği (2021). Pandemi döneminde kaybettiğimiz tüm să̆lık çalışanlarına saygryla... 4 Şubat 2021 tarihinde https://siyahkurdele.com/ adresinden erişildi. 
Yıldırım, A. ve Şimşek, H. (2016). Sosyal bilimlerde nitel araştırma yöntemleri. Ankara: Seçkin Yayınalık.

Yöney, D. (2010). Affects of organizational justice on organizational commitment in terms of survivor syndrome. Yayımlanmamış Yüksek Lisans Tezi, Marmara Üniversitesi, İstanbul.

\section{Kaynakça Bilgisi / Citation Information}

Güler, S. (2021). Pandemi günlerinde geride kalanlar sendromu: Sağlık çalışanları üzerinde bir inceleme. OPUS-Uluslararası Toplum Araştırmaları Dergisi, 17(Pandemi Özel Sayıs1), 3390-3413. DOI: 10.26466/opus. 875781 